\title{
Bentuk dan Gaya Kesenian Barongan Blora
}

\author{
Muhammad Jazuli ${ }^{\mathrm{a}, 1, *}$ Slamet MD ${ }^{\mathrm{b}, 2}$, Lesa Paranti ${ }^{\mathrm{c}, 3}$ \\ a Jurusan Pendidikan Seni Drama Tari dan Musik, Universitas Negeri Semarang, Gunungpati, Semarang, 50229 Indonesia \\ ${ }^{\mathrm{b}}$ Institut Seni Indonesia Surakarta J1. Ki Hadjar Dewantoro No. 19 Surakarta 57126, Indonesia \\ ${ }^{\mathrm{c}}$ Jurusan Seni Drama Tari dan Musik, Universitas Negeri Semarang, Gunungpati, Semarang, 50229 Indonesia \\ ${ }^{1}$ Jazuli61@mail.unnes.ac.id*; ${ }^{2}$ Mdslamet2008@yahoo.co.id ${ }^{3}$ lesa_tari@mail.unnes.ac.id \\ * Corresponding Author
}

Received 2020-02-06; accepted 2020-07-07; published 2020-09-16

\begin{abstract}
ABSTRAK
Seni Barongan merupakan cerminan kreativitas seni dan budaya Blora di Jawa Tengah yang bersifat kerakyatan dan syarat makna, seperti spontan, sederhana, kekeluargaan, kasar, menantang, dan berani karena memang benar. Sifat kerakyatan membuat masyarakat Blora memiliki kekuatan yang luar biasa dalam menjalani kehidupannya. Topeng singa dalam kesenian Barongan merupakan simbol kekuatan dan kekuatan. Simbol ini merupakan nilai yang sangat penting untuk digunakan dalam mendukung pendidikan karakter anak bangsa. Penelitian ini bertujuan untuk mengkaji bentuk dan corak seni Barongan (kearifan lokal) serta nilai-nilai yang terkandung di dalamnya sehingga dapat dimanfaatkan untuk kepentingan pendidikan karakter. Urgensi penelitian ini karena beberapa acara budaya tradisional di Blora memerlukan keterlibatan kesenian Barongan di dalamnya, seperti tradisi sedekah bumi, tradisi bersih kampung, dan tradisi lamporan. Hasil penelitian menginformasikan bentuk pertunjukan Barongan di Blora dibedakan menjadi dua yaitu bentuk arak-arakan dan drama. Gaya penampilan Barongan ditentukan oleh pola karyanya dan ragam gerak yang unik.
\end{abstract}

\section{Form and Art Style of Barongan Blora}

\section{ABSTRACT}

Barongan art is a reflection of the artistic and cultural creativity of Blora in Central Java, which has populist nature and conditions of meaning, such as spontaneous, simplicity, kinship, rough, challenging, and brave because it is true. The populist nature means that the Blora people have tremendous power in living their lives. The lion mask in Barongan art is a symbol of strength and might. This symbol is a significant value to be used in supporting the character education of the nation's children. This study aimed to examine the form and style of Barongan art (local wisdom) and the values contained therein so that it can be utilized for the benefit of character education. The urgency of this study is because some regular cultural events in Blora require the involvement of the Barongan art in them, such as the earth alms tradition, the clean village tradition, and the lamporan tradition. The results of the study inform the form of Barongan performances in Blora can be divided into two, namely the form of procession and drama. Barongan performance style is determined by the pattern of his work and a unique range of motion.

\section{KEYWORDS}

Barongan Art; Form;

Style.

This is an openaccess article under the CC-BY-SA

license

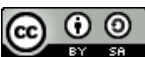

\section{Pendahuluan}

Kesenian Barongan merupakan kesenian rakyat yang amat populer di Blora, terutama pada masyarakat pedesaan. Di dalam Barongan tercermin sifat-sifat kerakyatan dan keakraban masyarakat Blora, yakni spontanitas, kekeluargaan, kesederhanaan, kasar, keras, kompak, dan keberanian yang dilandasi kebenaran. Barongan atau seni pertunjukan Barongan banyak terdapat di daerah Jawa Tengah, seperti kabupaten Blora, Rembang, Pati, Grobogan, dan Tegal. Oleh karena itu, dapat dikatakan bahwa Barongan merupakan salah satu kesenian khas Jawa Tengah. Keberadaan Barongan di Blora secara kuantitas lebih banyak dibandingkan dengan daerah lain yang ada di Jawa Tengah. 
Kata "Barongan" menunjuk pada suatu pelengkapan berupa topeng beserta asesorisnya yang menyerupai Singa Barong (Singa besar dan sangat buas) sebagai penguasa hutan angker. Peran Singo Barong atau disebut Gembong Amijoyo adalah tokoh utama dan dominan dalam cerita pertunjukan Barongan. Selain itu ada beberapa peran tokoh lainnya, yakni Bujangganong atau Pujonggo Anom, Joko Lodro atau Gendruwo, Pasukan berkuda, Reog Nayantaka, dan Untub (Gainah). Kesenian Barongan berbentuk tarian kelompok yang menirukan keperkasaan gerak seekor singa raksasa. Cerita dalam kesenian Barongan bersumber dari hikayat Panji, yaitu suatu cerita perjalanan Raden Panji Asmarabangun atau Pujonggo Anom dari kerajaan Kediri yang hendak melamar Dewi Sekartaji dari Kerajaan Jenggala. Penyajian pertunjukan Barongan diawali dari iring-iringan prajurit berkuda pengawal Raden Panji dan Singo Barong. Pertunjukan Barongan dilengkapi beberapa instrumen musik yang berfungsi sebagai pengiringnya, yakni instrumen kendhang, gedhuk, bonang, saron, demung dan kempul. Namun dalam perkembangannya ada beberapa penambahan instrumen modern, seperti drum, terompet, kendhang besar dan keyboard. Adakalanya dalam beberapa peristiwa pertunjukannya dipadukan dengan kesenian Campursari.

Perkembangan Barongan di Kabupaten Blora sangat pesat di tengah kehidupan masyarakat modern. Beberapa peristiwa budaya tradisi mensyaratkan keterlibatan kesenian Barongan di dalamnya, seperti tradisi sedekah bumi, tradisi bersih desa, dan tradisi lamporan (tolak balak). Dalam tradisi lamporan mengharuskan keterlibatan Barongan karena tokoh Singo Barong dianggap sebagai pengusir balak. Selain itu, Barongan Blora telah menorehkan beberapa prestasi saat mengikuti parade maupun festival budaya baik di tingkat provinsi sampai tingkat internasional. Penampilan Barongan Blora dalam Parade Seni Budaya di Semarang tahun 2010 lalu berhasil meraih Juara 1 dari 35 perwakilan Kabupaten/Kota se Jawa Tengah. Pada tahun 2011 Barongan Blora sebagai wakil kesenian Provinsi Jawa Tengah dalam Parade Seni Budaya di Taman Mini Indonesia Indah. Pada tahun yang sama Barongan Blora tampil dalam event Jogjakarta International Ethnic Culture Festival 2011 di Monumen Serangan Umum 1 Maret Yogyakarta dan meraih Juara 2, mengalahkan beberapa kesenian dari daerah lain termasuk kesenian dari luar negeri.

Sungguhpun demikian, tulisan dari hasil penelitian ini tidak terlepas dari penelitian sebelumnya yakni penelitian (Sudiana 1999) tentang "Desakralisasi Tari Barong dalam Kehidupan Sosial Budaya Masyarakat Bali". Penelitian ini menginformasikan bahwa bentuk pertunjukan Seni Barong di Bali mulai menghilangkan nilai kesakralan (ritual) karena perkembangan pariwisata. Penelitian (Rusiani 2006) berjudul "Struktur dan Fungsi Pertunjukan Kesenian Barongan Dalam Upacara Ritual pada Bulan Sura di Dusun Gluntungan Desa Banjarsari Kecamatan Kradenan Kabupaten Grobogan". Penelitian ini menginformasikan bahwa kesenian Barongan sering dipentaskan dalam acara pernikahan dan khitanan. Pertunjukan Barongan dalam upacara ritual di Dusun Gluntungan memiliki struktur dan fungsi yang berbeda dengan pertunjukan dalam acara hiburan dan acara ritual pernikahan. Namun prosesi pertunjukan Barongan dalam upacara ritual terdiri dari tiga bagian, yaitu (1) bagian pembuka berupa acara selamatan, (2) bagian inti sajian terdiri dari dua sub bagian yaitu ritual kutuk (dupani) dan pertunjukan Barongan, dan (3) bagian penutup (arak-arakan Barongan mengelilingi dusun). Sedangkan elemen-elemen pertunjukan kesenian Barongan di Dusun Gluntungan meliputi (1) ragam gerak, (2) iringan, (3) tata rias dan busana, (4) waktu dan tempat pertunjukan, serta (5) sesaji. Ada empat fungsi pertunjukan kesenian Barongan di Dusun Gluntungan, yaitu (1) sebagai sarana pemenuhan kebutuhan estetis, (2) sebagai sarana ungkapan rasa syukur, (3) sebagai ritual ruwatan, (4) sebagai sarana integratif bagi sesama anggota masyarakat.

Penelitian selanjutnya dilakukan oleh Slamet MD menginformasikan tentang kehidupan kesenian Barongan di Blora (termasuk sistem produksinya) serta perkembangannya dalam peta perubahan kehidupan politik dan sosial yang menyertainya. Perkembangan Barongan sangat dipengaruhi oleh kehidupan politik yang melatarbelakanginya (Slamet 2014). Penelitian Pambudi dkk tentang "Perkembangan Bentuk Topeng Barongan dalam Ritual Murwakala di Kabupaten Blora" juga menjelaskan tentang perkembangan bentuk topeng Barongan dipengaruhi situasi zaman, terutama berkait dengan kekuasaan (Pambudi, Iswidayati, and Supriyanto 2015). Penelitian Murni dkk yang berjudul "Seni Barongan di Kabupaten Tegal: Ekspresi Simbolik Budaya Masyarakat Pesisiran". Penelitian ini menginformasikan bahwa seni Barongan merupakan salah satu bentuk ekspresi budaya pesisiran di Tegal, sedangkan bentuk topeng dan kostumnya dipengaruhi unsur-unsur keislaman (Murni, Rohidi, and Syarif 2016). Berdasarkan hasil kajian pustaka pertunjukan Barongan di Jawa Tengah dibedakan menjadi dua gaya, yakni gaya pedalaman dan gaya pesisiran. Contohnya seni 
Barongan di Tegal bergaya pesisiran dan Barongan bergaya pedalaman adalah Barongan Blora dan sekitarnya. Berdasar fenomena di atas, tulisan ini mengkaji bentuk dan gaya kesenian Barongan Blora. Urgensi kajian seperti ini karena berkaitan dengan upaya untuk mengembangkan, memfungsikan nilai-nilai luhur (etika moral dan adat), menyelamatkan, melindungi nilai-nilai yang terkandung di dalam pertunjukan Barongan. Selain itu juga sebagai wahana pendidikan karakter (pendidikan nilai) anak bangsa dan untuk meneguhkan sebuah identitas budaya lokal.

\section{Metode}

Penelitian ini merupakan jenis penelitian deskriptif kualitatif, dengan tujuan untuk menggambarkan serta menjelaskan seni pertunjukan Barongan di Blora sebagaimana adanya. Dalam pandangan kontekstual, menganalisis Barongan sebagai seni pertunjukan perlu pendekatan multidisiplin (Putra 1999); (Soedarsono 2002); (Supanggah 2005). Untuk itu penelitian ini digunakan teori struktural-fungsional dan tindakan sosial sebagai latar kontekstual (Jazuli 2011), sedangkan dalam pandangan tekstual digunakan pendekatan bentuk dan gaya pertunjukan (Jazuli 1994); (Jazuli 2008); (Sumandiyo 1996).

Menurut teori fungsionalisme-struktual bahwa masyarakat merupakan sistem sosial yang terdiri atas bagian-bagian yang saling berkaitan dan saling menyatu dalam keseimbangan. Robert K. Merton merupakan tokoh fungsionalisme-struktural yang mengembangkan middle range theory dengan berdasarkan data empiric (Merton 1949). Teori yang dikembangkan ialah bentuk penyesuaian yang meliputi konformitas (untuk mcncapai tujuan yang disepakat masyarakat digunakan cara yang disepakati masyarakat); inovasi (untuk mencapai tujuan yang disepakati masyarakat digunakan cara yang baru); ritualisme (terlalu mementingkan cara sehingga tujuan terlupakan); retreatisme (menolak cara dan tujuan yang telah disepakati masyarakat), dan rebellion (menolak cara dan tujuan yang lama, kemudian mengajukan cara dan tujuan yang baru). Selain itu Merton juga memperkenalkan teori manifest (yang tampak/kelihatan) dan laten (tersembunyi/ belum nampak) dalam setiap kegiatan masyarakat. Jadi teori ini lebih menekankan keteraturan dan mengabaikan konflik maupun perubahan dalam masyarakat (Jazuli 2011). Apabila kata 'masyarakat' diturunkan atau digantikan 'seni Barongan', maka seni dapat dipandang sebagai penyeimbang keberpihakan terhadap aktivitas instrumental, seperti pekerjaan rutin setiap hari dan fenomena dalam kesenian Barongan. Seni merupakan interes ekspresif yang mereduksi ketegangan yang diciptakan oleh peranan instrumental. Seni mampu mereduksi konflik sosial dan mengalihkan dari sumber agresi tertentu dengan menciptakan rasa aman dari dorongan bermusuhan.

Untuk mengkaji tindakan para pelaku dalam kesenian Barongan digunakan teori tindakan sosial Max Weber. Asumsi teoretisnya bahwa (1) tindakan manusia muncul dari kesadarannya sendiri maupun dari situasi eksternal dalam posisinya sebagai objek disebut 'kesadaran subjektif', (2) manusia sebagai subjek dalam bertindak selalu memiliki tujuan, (3) dalam bertindak manusia menggunakan cara, alat, prosedur, metode, dan perangkat yang dipandang dapat digunakan untuk mencapai tujuan, (4) keberlangsungan tindakan manusia hanya dibatasi oleh suatu situasi dan kondisi yang tidak bisa diubah dengan sendirinya, (5) manusia senantiasa memilah, memilih, dan menilai tindakan yang akan, sedang, dan yang telah dilakukan, (6) aturan-aturan atau prinsip moral diharapkan muncul pada saat pengambilan keputusan, (7) kajian tentang antar hubungan sosial memerlukan teknik yang bersifat subjektif, seperti verstehen, imajinasi, rekonstruksi simpati atau seakan-akan mengalami sendiri (vicarious experience) (Jazuli 2011).

Suatu bentuk pertunjukan (tari) akan tampak dari keseluruhan penyajian yang mencangkupi struktur penyajian, paduan antarelemen tari (gerak, ruang, waktu) maupun berbagai unsur pendukung penyajiannya, seperti iringan, pola lantai, tata busana, rias, tempat, dan tata cahaya (Jazuli 2008, 7). Semua elemen tersebut terefleksi pada bentuk pertunjukannya. Sebuah gaya dalam seni (tari) dapat dipahami sebagai suatu ekspresi karya seni yang menunjuk pada ciri khas atau corak yang terdapat pada struktur, bentuk dan teknik penampilannya, terutama menyangkut pembawaan individual (kadang juga kekhasan dari suatua momunitas atau sebuah grup) maupun ciri sosial budaya masyarakat lingkungannya. Representasi gaya, nampak pada bagian-bagian dari suatu karya seni maupun sebagai suatu kesatuan corak dan karakteristik (Hidayat 2011,27). Representasi 'gaya' tersebut dapat dinikmati secara visual maupun dirasakan melalui penghayatan. 
Lokasi penelitian adalah empat desa yakni Desa Berbak, Desa Sambongrejo Kecamatan Ngawen, Desa Todanan, dan Desa Kunden. Penetapan keempat desa tersebut dengan pertimbangan bahwa ketika dilakukan studi awal (penjajagan) ditemukan prinsip persamaan dan perbedaan pertunjukan Barongan pada sebagian besar desa yang ada di Kabupaten Blora. Selain itu, keempat desa tersebut banyak terdapat grup atau kelompok Barongan yang masih eksis dan terkenal hingga saat ini. Popularitas grup atau kelompok Barongan karena senantiasa mengadakan inovasi dan kreasi untuk menarik masyarakat penonton (hiburan). Misalnya grup Barongan Sekar Joyo, grup Barongan Seloganti, dan yang paling populer grup Barongan Risang Guntur Seto. Desa Berbak dan Sambongrejo dipilih sebagai lokasi penelitian karena masih sering menyelenggakan Barongan untuk ritual sedekah bumi dan tolak balak. Prosedur dan tahapan penelitian meliputi: (1) pengumpulan data melalui observasi langsung, wawancara mendalam dan studi dokumen; (2) pengorganisasian dan indentifikasi hasil pengumpulan data serta dilakukan focus group discussion (FGD) triangulasi untuk menetapkan keabsahan data; (3) analisis data mencakup bentuk dan gaya penyajiannya. Langkahlangkah observasi dalam penelitian ini adalah 1) menggunakan alat dan bahan seperti buku catatan, kamera, alat tulis dan video perekam, 2) pengamatan pertunjukan Barongan yang difokuskan pada bentuk dan gaya penyajiannya.

Wawancara mendalam dilakukan dengan pimpinan dan para anggota grup Barongan. Dalam penelitian ini wawancara dilakukan dengan informan utama, yakni (1) Nurcahyo (pakar Barongan dari Berbak), (2) Adi Wibowo ketua grup Barongan Risang Guntur Seto, (3) Dina koreografer grup Barongan (3) beberapa pelaku kesenian Barongan Blora, di antaranya adalah Anto Singo Joyo dan Rusman (pegawai kelurahan). Dari Ari Wibowo dan Nurcahyo diperoleh informasi tentang asal usul Barongan di Blora, pembinaan organisasi dan fungsi Barongan bagi masyarakat sekitarnya. Dari Dina dan Nurcahyo diperoleh informasi mengenai model penggarapan, fungsi yang terkait dengan kepentingan Barongan dipertunjukkan, teknik penyajian, pelatihan hingga penampilan kesenian Barongan. Dari pelaku Barongan, Anto Singo Joyo diperoleh informasi tentang teknik permainan topeng Barongan. Dari Rusman sebagai aparatur pemerintah mendapat informasi mengenai posisi dan fungsi kelurahan (pemerintah) dalam partisipasi maupun pengembangan Barongan.

\section{Hasil dan Pembahasan}

Kesenian Barongan Blora sebagai bentuk (model) seni pertunjukan ditampilkan dalam dua bentuk, yaitu dalam bentuk arak-arakan dan dramatari. Bentuk pertunjukan arak-arakan atau pawai seringkali dapat ditemui pada acara ritual, seperti lamporan, ruwatan, sedekah bumi, hajat khitanan maupun karnaval budaya. Masyarakat Blora menggunakan Barongan sebagai sarana untuk mengusir wabah atau penyakit dengan mengarak Barongan keliling desa (terutama untuk khitanan). Oleh karena itu sebelum arak-arakan dilaksanakan diawali dengan talu kemudian slametan (doa bersama) sesuai dengan kepentingannya. Jika arak-arakan Barongan untuk khitanan, maka isi doanya selaras dengan khitanan. Demikian pula jika untuk kepentingan lamporan, ruwatan, dan sedekah bumi, isi doa berkitan dengan kepentingan yang menyertainya. Pertunjukan Barongan pada arak-arakan tidak mementingkan segi estetisnya melainkan pada tujuan pokok untuk tolak balak. Tujuan Arak-arakan Barongan adalah untuk memperoleh keselamatan yang didasari kepercayaan dan kekuatan magi yang dimiliki oleh Barongan. Masyarakat memiliki kepercayaan bahwa Barongan merupakan perwujudan binatang mitologi harimau yang dianggap memiliki kekuatan magi untuk melindungi dari marabahaya. Misalnya Barongan arak-arakan pada acara ritual sedekah bumi, peran kesenian Barongan sebagai pengiring atau pengawal sesaji, yakni mengawal pembawa sesaji yang berpindah dari satu tempat ke tempat lain yang dinamakan punden (tempat yang dianggap keramat). Punden bisa berupa sebuah tempat peninggalan seorang tokoh (petilasan cikal bakal), sumur atau sendang, dan makam. Jadi Barongan berfungsi untuk mengawal pembawa sesaji dari punden yang satu ke punden yang lainnya.

Bentuk pertunjukan Barongan dramatari terbagi dalam tiga bagian, yaitu sebelum pertunjukan, pada saat pertunjukan, dan akhir pertunjukan. Pada bagian sebelum pertunjukan terdiri atas subbagian, yakni slametan dan doa bersama, kemudian talu, dan diakhiri dengan padupan sebagai penutup bagian sebelum pertunjukan. Bagian pertunjukan terbagi beberapa adegan, yaitu adegan Kiprahan Barongan, tari Bujangganong, Jaranan, Barongan Tunggal, Panakawan, adegan perang Joko Lodro, dan Barongan Kerah sebagai adegan penutup pertunjukan. Barongan dramatari juga melibatkan seluruh tokoh pendukung cerita Barongan dan elemen-elemen penampilan sebagaimana 
bentuk arak-arakan tetapi orientasinya lebih kepada kepentingan hiburan atau tontonan. Pergeseran fungsi seni dari fungsi ritual yang bersifat sakral menjadi fungsi hiburan/tontonan yang bersifat profane terjadi akibat perubahan kehidupan masyarakat yang dinamis (Dewi 2016).

Perubahan budaya atau pergeseran nilai budaya yang begitu cepat sekarang ini, tampaknya telah mempengaruhi segala aspek kehidupan dalam bermasyarakat, tak terkecuali dalam dunia seni pertunjukan yang syarat dengan nilai dan filsafat hidup bagi masyarakat pendukungnya. Perubahan budaya yang tidak dapat diantisipasi dengan baik oleh para pelaku budaya, khususnya kesenian Barongan, lambat laun telah terseleksi oleh alam dan digantikan dengan kebutuhan batin yang lebih praktis dan menghibur (budaya modern). Sesuai yang dikatakan oleh Koentjaraningrat, bahwa perubahan kebudayaan termasuk kesenian tetap berorientasi pada kedua dimensi waktu, yaitu masa lampau dan masa sekarang. Pada masa sekarang, perkembangan kebudayaan dihadapkan pada perkembangan ilmu pengetahuan dan teknologi (Hasan 1970, 108). Selaras dengan pendapat tersebut, dapat dikatakan bahwa setiap perubahan berarti pergantian orientasi hidup yang dilahirkan oleh nilainilai baru (modern) sebagai hasil kreativitas manusia dalam suatu masyarakat dan berorientasi kepada kepentingan masyarakat pada zamannya (Jazuli 2001, 186). Oleh karena itu, seniman Barongan Blora selalu berupaya untuk mengikuti perubahan budaya. Sebagai seniman yang kreatif, mereka telah tanggap untuk menghadapi perubahan dan tuntutan zaman, termasuk dalam mempertahankan pertunjukan Barongan agar tetap survive. Kini, seniman Barongan Blora telah melek literasi dan berpengetahuan tentang perkembangan teknologi. Melek literasi artinya memahami situasi dan kondisi zaman, sedangkan pengetahuan yang dimaksud adalah kompetensi tentang bidang keahliannya. Dalam hal ini adalah menginovasi bentuk pertunjukan Barongan Blora berwawasan nilai-nilai kedaerahan atau ke-lokal-an, termasuk gaya dari setiap grup Barongan. Langkah semacam inilah merupakan tindakan penuh arti menurut teori tindakan sosial. Sekaligus juga relevan dengan teori fungsional-struktural dari Robert K. Merton, yaitu sebagai bentuk penyesuaian tuntutan zaman yang meliputi konformitas (untuk mencapai tujuan yang disepakat masyarakat digunakan cara yang disepakati masyarakat); inovasi (mencapai tujuan yang disepakati masyarakat dan digunakan cara yang baru); ritualisme (terlalu mementingkan cara sehingga tujuan terlupakan); retreatisme (melakukan cara dan tujuan yang telah disepakati masyarakat), dan rebellion (menolak cara dan tujuan yang lama, kemudian mengajukan cara dan tujuan yang baru) (Jazuli 2011).

Sesuai dengan teori perubahan yang dikemukakan oleh Alvin Boskoff bahwa faktor-faktor yang mempengaruhi perubahan Barongan di Blora adalah faktor internal dan faktor eksternal (Boskoff 1964). Faktor internal terlihat dari berbagai hal yang berhubungan dengan kompetensi dan kreativitas seniman dalam penggarapan/mengolah pertunjukan Barongan. Pengembangan ragam gerak, kostum, properti terutama kreasi rupa dan karakter topeng dalam kesenian Barongan. Juga bentuk pertunjukan Barongan yang tampak dari keseluruhan penyajian yang mencangkupi paduan antarelemen tari (gerak, ruang, waktu) maupun berbagai unsur pendukung penyajiannya, seperti iringan, pola lantai, tata busana, rias, tempat, dan tata cahaya (Jazuli 2008, 7). Semua elemen tersebut terefleksi pada bentuk pertunjukannya. Struktur penyajian Barongan yang terdiri dari bagian awal, bagian pokok/inti, dan bagian akhir pertunjukan. Setiap bagian terdiri atas sub-bagian (kadangkala disebut "adegan").

Berdasar faktor internal inilah bentuk pertunjukan Barongan dapat dibedakan menjadi dua, yakni bentuk pertunjukan Arak-arakan dan bentuk pertunjukan Dramatari. Bentuk pertunjukan arak-arakan (pawai) dapat ditemui pada acara yang bersifat ritual, seperti khitanan, lamporan (sekarang seperti karnaval budaya), dan ritual lainnya bandingkan dengan (Kusmayati 2000). Penampilan Barongan arak-arakan memiliki elemen-elemen penyajian, yaitu cerita, gerak tari, iringan, rias dan busana, serta tempat yang sudah ditentukan/dipatenkan (Soedarsono 2002). Pada bentuk pertunjukan dramatari terdiri atas sub-bagian pra-pertunjukan, saat pertunjukan, dan akhir pertunjukan. Bagian prapertunjukan terdiri atas adegan slametan, doa bersama, talu, dan padupan dapat dikatakan masih mengadopsi sifat ritual. Bagian pertunjukan terdiri atas beberapa adegan, yakni adegan Kiprahan Barongan, Bujangganong, Jaranan, Panakawan, Panakawan Duta, dan Perang Joko Lodro. Bagian akhir pertunjukan diakhiri dengan adegan Barongan Kerah (bertengkar) sebagai klimaks penyajian. Secara singkat dapat dirumuskan bahwa bentuk pertunjukan Barongan Arak-arak sering digunakan untuk kepentingan ritual, sedangkan bentuk pertunjukan Barongan dramatari lebih melayani kepentingan hiburan. Kedua bentuk pertunjukan Barongan tersebut sering menampakkan sifat spontanitas, kesederhanaan, keras, kompak dalam hal gerak, kreatifitas ekspresi wajah (permainan topengnya) dan dilakukan dengan penuh keberanian. Tentu penampilan seperti itu tidak akan berhasil 
dengan baik manakala tanpa latihan secara serius dan intensif karena bisa menimbulkan resiko cedera fisik pemain/pelakunya.

Faktor eksternal yang dimaksud disini adalah faktor-faktor di luar pertunjukan Barongan tetapi memiliki pengaruh bagi pertumbuhan dan kelangsungan hidup Barongan di Blora. Mengingat masyarakat Blora termasuk masyarakat agraris yang hidup dari hasil pertanian, maka kehidupannya masih terpola oleh berbagai kepercayaan yang berhubungan dengan hal-hal gaib, terutama percaya adanya suatu kekuatan yang bisa mempengaruhi hasil panen dan ternak peliharaannya. Masyarakat masih percaya melakukan berbagai kegiatan ritual untuk mencapai tujuannya. Barongan dianggap memiliki kekuatan magi untuk melindungi (magi proteksi) dari gangguan ruh jahat (tolak bala). Pertunjukan Barongan dalam rangka tolak balak dilakukan secara gotong royong oleh warga masyarakat yang bersangkutan. Seluruh biaya yang dikeluarkan untuk pertunjukan Barongan ditanggung bersama oleh warga desa. Barongan sering ditampilkan dalam hajatan khitanan dan perkawinan oleh masyarakat Blora, terutama masyarakat pedesaaan. Barongan dianggap memiliki pengaruh terhadap hajatan atau perkawinan karena dengan menanggap Barongan, anak yang khitan atau pengantin akan mendapatkan perlindungan dari gangguan roh jahat. Faktor eksternal yang lain adalah relasi dengan pihak lain, seperti tokoh masyarakat, pejabat, lembaga pemerintah maupun swasta, dan perusahaan. Pihak lain inilah yang akan menghidupi kesenian Barongan dengan cara menanggap (mengontrak) untuk kepentingan dan keinginannya (perorangan, kelompok, lembaga). Oleh karena itu, setiap grup Barongan selalu berupaya menjalin relasi dengan siapa pun dan pihak mana pun yang dipandang mampu menanggap Barongan.

Sebuah gaya dalam seni (tari) dapat dipahami sebagai suatu ekspresi karya seni yang menunjuk pada ciri khas atau corak yang terdapat pada struktur, bentuk dan teknik penampilannya, terutama menyangkut pembawaan individual (kadang juga kekhasan dari suatu komunitas atau sebuah grup) maupun ciri sosial budaya masyarakat lingkungannya. Representasi gaya, nampak pada bagian-bagian dari suatu karya seni maupun sebagai suatu kesatuan corak dan karakteristik (Hidayat 2011, 27). Representasi 'gaya' tersebut dapat dinikmati secara visual maupun dirasakan melalui penghayatan. Demikian pula dengan Barongan Blora bila ditinjau dari gayanya, lebih mengarah pada ciri khas atau corak yang terdapat pada bentuk dan teknik gerak, terutama menyangkut pembawaan individual (pelakunya) maupun kelompok (sebuah grup Barongan). Selain itu juga bisa dari ciri lingkungan sosial budaya masyarakat yang melatarbelakangi kehadiran struktur penyajian, bentuk, ragam gerak dan teknik gerak tari Barongan. Gaya ragam gerak tari sesuai dengan ciri khas pribadi penari Barongan sangat beragam dan bervariasi. Setiap penari Barongan bisa berbeda dalam hal gaya, meskipun melakukan ragam gerak yang sama. Ciri khas individu ini biasanya sudah sangat dikenal dan menjadi prinsip yang kuat dari suatu grup Barongan tempat penari tersebut berasal bandingkan dengan (Prihatini 2007, 41). Adanya gaya yang melekat pada sebuah grup Barongan dan pribadi pemainnya (penarinya) menjadikan pertunjukan Barongan berbeda antara grup satu dengan grup lainnya, antara penari yang satu dengan penari yang lainnya. Keberadaan gerak tari dalam Barongan, baik sengaja atau tidak disengaja dikembangkan oleh grup dan atau pemainnya mengakibatkan ciri yang khas, kemudian menjadi identitas (pribadi maupun grup) yang pada gilirannya juga bisa menjadi ciri khas daerah Blora. Demikian representasi gaya Barongan nampak pada bagian-bagian maupun dari suatu kesatuan corak dan karakteristik yang menyertainya. Representasi 'gaya' tersebut dapat dinikmati secara visual maupun dirasakan melalui penghayatan. Citra visual dari suatu representasi gaya gerak Barongan, seperti pada ragam dhekeman, geter, senggot, gebyah, thathakan dan bekur. Citra visual juga muncul pada ragam gerak setiap tokoh, seperti tokoh Joko Lodra, Bujangganong, Punakawan, dan Jaranan. Citra visual dalam tokoh-tokoh tersebut tampak dari ekspresi wajah (mengekspresikan topengnya) atau disebut polatan, yang didukung atau dikuatkan oleh ciri tata rias dan kostumnya.

\section{Kesimpulan}

Berdasarkan hasil penelitian mengenai bentuk dan gaya penyajian pertunjukan Barongan yang dilakukan oleh grup-grup kesenian Barongan di Blora, dapat disimpulkan seperti berikut ini. Pertama, bentuk pertunjukan Barongan Blora dibedakan menjadi dua, yaitu bentuk arak-arakan, dan pertunjukan dramatari. Bentuk pertunjukan arak-arakan atau pawai dapat ditemui pada acara bersifat ritual. Bentuk pertunjukan dramatari melayani kepentingan hiburan atau tontonan. Kedua, Gaya pertunjukan Barongan Blora tampak dari kekhasan atau kekhususan yang ditandai oleh ciri fisik terutama ragam geraknya dan pola garap (kerja kreatif) penyajiannya. Hal ini dilakukan berdasarkan 
selera grup dengan kawasan (budaya) tertentu dan juga kreatifitas individu (gaya pribadi pelakunya) yang diakui eksistensinya oleh grup-grup lainnya. Ketiga, nilai-nilai dari pertunjukan Barongan yang dapat dimanfaatkan untuk kepentingan pendidikan maupun untuk peningkatan pendapatan adalah sifat spontanitas, kesederhanaan, keras, kompak, dan sifat keberanian yang dilandasi kebenaran. Dari hasil penelitian tersebut, untuk kontinuitas ke masa depan pertunjukan Barongan Blora harus terus ditingkatkan kualitasnya, seperti menciptakan berbagai inovasi dalam penampilan yang dilengkapi dengan hasil perkembangan teknologi tetapi tetap tidak menafikan nilai-nilai leluhur yang ada di dalamnya. Secara kuantitas pertunjukan Barongan harus selalu ditampilkan pada peristiwa penting di Blora, syukur dikembangkan terus ke tingkat nasional dan internasional.

\section{References}

Boskoff, Alvin. 1964. Recent Theories of Social Change, in Ed. Warner J. Cahnman Dan Alvin Boskoff, Sociology and History: Theory and Research. London: The Free Press of Glencoe. Available at: Google Scholar

Dewi, Anggraeni Purnama. 2016. "Komodifikasi Tari Barong Di Pulau Bali (Seni Berdasarkan Karakter Pariwisata)." Panggung 26 (3). Available at: Google Scholar

Hasan, Fuad. 1970. "Koentjaraningrat, Metode-Metode Penelitian Masyarakat.” Jakarta: Gramedia. Available at: Google Scholar

Hidayat, Robby. 2011. Koreografi \& Kreativitas Pengetahuan Dan Petunjuk Praktikum Koreografi. Yogyakarta: Kendil Media Pustaka Seni Indonesia. Available at: Google Scholar

Jazuli, Muhammad. 1994. Telaah Teoritis Seni Tari. Semarang: IKIP Semarang Press. Available at: Google Scholar

. 2001. Paradigma Seni Pertunjukan: Sebuah Wacana Seni Tari, Wayang, Dan Seniman. Yogyakarta: Yayasan Lentera Budaya. Available at: Google Scholar

- 2008. Pendidikan Seni Budaya Suplemen Pembelajaran Seni Tari. Semarang: Universitas Negeri Semarang Press. Available at: Google Scholar

—. 2011. Sosiologi Seni: Pengantar Dan Model Studi Seni. Sebelas Maret University. Available at: Google Scholar

Kusmayati, A M Hermien. 2000. Arak-Arakan: Seni Pertunjukan Dalam Upacara Tradisional Di Madura. Yogyakarta: Yayasan Untuk Indonesia. Available at: Google Scholar

Merton, R K., 1949. Social Theory and Social Structure. New York: The Free Press. Available at: Google Scholar

Murni, Endri Sintiana, Tjetjep Rohendi Rohidi, and Muh Ibnan Syarif. 2016. "Topeng Seni Barongan Di Kendayakan Tegal: Ekspresi Simbolik Budaya Masyarakat Pesisiran.” Catharsis 5 (2): 150-59. Available at: Google Scholar

Pambudi, Fivin Bagus Septiya, Sri Iswidayati, and Teguh Supriyanto. 2015. "Perkembangan Bentuk Topeng Barongan Dalam Ritual Murwakala Di Kabupaten Blora." Catharsis 4 (2): 83-91. Available at: Google Scholar

Prihatini, Nanik Sri. 2007. Ilmu Tari Joged Tradisi Gaya Kasunanan Surakarta. Surakarta: Pengembangan Ilmu Budaya bekerjasama dengan ISI Press Surakarta. Available at: Google Scholar

Putra, Heddy Shri Ahimsa. 1999. Ketika Orang Jawa Nyeni. Diterbitkan Oleh Galang Usat Penelitian Kebuday. Available at: Google Scholar

Rusiani, Rina Veri. 2006. "Struktur Dan Fungsi Pertunjukan Kesenian Barongan Dalam Upacara Ritual Pada Bulan Sura Di Dusun Gluntungan Desa Banjarsari Kecamatan Kradenan Kabupaten Grobogan.” Universitas Negeri Semarang. Available at: Google Scholar

Slamet, M D. 2014. "Barongan Blora Menari Di Atas Politik Dan Terpaan Zaman." Surakarta: Citra Sains LPKBN. Available at: Google Scholar

Soedarsono, R M. 2002. "Seni Pertunjukan Indonesia Di Era Globalisasi, Edisi Ketiga Yang Diperluas.” Yogyakarta: Gadjah mada University Press. Available at: Google Scholar 
Sudiana, I. 1999. "Desakralisasi Tari Barong Dalam Kehidupan Sosial Budaya Masyarakat Bali." Yogyakarta: Universitas Gadjah Mada. Available at: Google Scholar

Sumandiyo, Hadi. 1996. Aspek-Aspek Dasar Komposisi Kelompok Yogyakarta. Yogyakarta: Manthili. Available at: Google Scholar

Supanggah, Rahayu. 2005. Garap: Salah Satu Konsep Pendekatan/Kajian Musik Nusantara” Dalam Menimbang Pendekatan Pengkajian \& Penciptaan Musik Nusantara. Surakarta: ISI Surakarta. Available at: Google Scholar. 